Jurnal Kejaora: Jurnal Kesehatan Jasmani dan Olah Raga

ISSN: 2541-5042 (Online)

ISSN: 2503-2976 (Print)

Volume 5 Nomor 1, Edisi April 2020

\title{
PEMANFAATAN MEDIA PEMBELAJARAN BERBASIS ICT OLEH GURU PENJAS KOTA BANDAR LAMPUNG
}

\author{
Lungit Wicaksono', Dimas Duta Putra Utama² \\ 1,2Program Studi Penjaskes, FKIP Universitas Lampung \\ Email: lungit83@gmail.com¹, dimasutama33139@gmail.com² \\ DOI: https://doi.org/10.36526/kejaora.v5i1.846
}

\begin{abstract}
ABSTRAK
Penggunaan Media Pembelajaran Information, Communication and Technology (ICT) dunia pendidikan sudah menjadi kebutuhan yang mendasar untuk meningkatkan proses pendidikan. Penggunaan ICT pada guru olahraga (penjasorkes) baik di sekolah dasar dan menengah di Kota Bandar Lampung relatif minim. Hal ini ditunjukan oleh masih sedikit jumlah guru menggunakan media ICT dalam pembelajaran gerak yang sangat cepat dan sulit diamati secara langsung. Kemampuan ICT yang dimiliki setiap guru Penjasorkes berbeda-berbeda baik dari penerapan maupun implementasinya. Penelitian ini bertujuan untuk mengetahui pemanfaatan media pembelajaran berbasis ICT bagi guru penjasorkes di Kota Bandar Lampung. Penelitian menggunakan metode deskriptif kuantitatif. Prosedur pengumpulan data memalui angket yang disebar pada guru Penjasorkes. Teknik analisis pada penelitian ini yaitu reduksi data, penyajian data dan penarikan kesimpulan. hasil penelitian yang dilakukan kepada guru Penjasorkes di Kota Bandar Lampung sekolah dasar dan menegah menunjukan pada kategori sering menggunakan 38 guru dengan persentase $41,30 \%$ ini dikategorikan pada sering memanfaatkan ICT dan digunakan dalam pembelajaran rata-rata $8 x$ persemester, kategori Sering 19 Guru dengan presentase 20,65\% dengan kategori memanfaatkan ICT namun tidak sering dilihat dari 6x pertemuan persemester, kategori sedang 14 Guru dengan persentase $15,21 \%$ guru dalam memanfaatkan ICT kategori sedang karena kurangnya pengetahuan dan penggunaan ICT tersebut, Kategori Kurang 9 Guru dengan persentase $9,78 \%$ kurang memanfaatkan ICT karena fasilitas yang terbatas dan pengetahuan guru tentang ICT yang kurang, dan kategori kurang sekali menggunakan 8 guru dengan persentase 8,69\% dalam pemanfaatan ICT Persemester kurang 2 kali mengggunakan. Dengan demikian guru sudah memanfaatkan ICT sebagai media pembelajaran, namun belum maksimal digunakan karena kondisi media pembelajaran dari fasilitas sudah memadai akan tetapi dengan jumlah yang terbatas serta perlu adanya pelatihan.
\end{abstract}

Kata Kunci: ICT,Pengetahuan, Penggunaan, Pemahaman

\section{PENDAHULUAN}

Perkembangan ilmu pengetahuan dan teknologi dalam abad ke 21 mempunyai ciri eksponensial perkembangan teknologi semakin lama semakin cepat tidak terkendali, karena hasil dari suatu tahap menjadi dasar dan alasan bagi tahap selanjutnya yang menjadikan perubahan lebih cepat. Dilihat dari peran pendidikan teknologi merupakan pendorong utama bagi penciptaan nilai tambah untuk kemudahan dalam pendidikan. Nilai tambah ini dinikmati oleh para pelaku pendidikan yang harus memiliki kualitas yang baik, sehingga menaikkan kualitas pendidikan di daerahnya. Dengan naiknya kualitas kehidupan maka semakin besar pula dorongan untuk penciptaan pendidikan yang modern dan lebih memudahkan yang akan menerima pendidikan tersebut. Tidak mengherankan nantinya bahwa bukan saja perkembangannya yang akansemakin cepat, akan tetapi peranan ilmu pengetahuan dan teknologi dalam lingkup masyarakat modern lama-kelaman bertambah penting. Pengembangan ilmu pengetahuan dan teknologi berjalan aktif di segala bidang dalam hal ini pada bidang pendidikan yang berada di Indonesia.

Menurut Redhana (2019) Abad 21 dapat dikatakan sebagai abad pengetahuan 
Jurnal Kejaora: Jurnal Kesehatan Jasmani dan Olah Raga

ISSN: 2541-5042 (Online)

ISSN: 2503-2976 (Print)

Volume 5 Nomor 1, Edisi April 2020

dengan yang mengedepankan hasil riset ditandai dengan terjadinya transformasi besar-besaran dari masyarakat agraris menuju masyarakat industri modern dan berlanjut pada masyarakat yang berpengetahuan tinggi. Proses perubahan ini juga ditandai dengan adanya seperangkat perubahan sosial dan budaya masyarakat yang diakibatkan munculnya globalisasi dan derasnya arus informasi yang semakin bebas. Di tengah ketat dan ketidakpastian serta tantangan yang akan dihadapi setiap orang ini, dibutuhkan perubahan paradigma berfikir dalam sistem pendidikan yang harus dapat menyediakan dengan seperangkat keterampilan abad 21 yang dibutuhkan oleh peserta didik dalam pendidikan guna menghadapi setiap aspek kehidupan global dan secara luas.

Pada Laporan BSNP (2011) Di Indonesia kesadaran tentang pentingya keterampilan pada abad 21 sendiri dapat ditemukan dan dijelaskan dalam dokumen yang dikeluarkan oleh Badan Nasional Standar Pendidikan tahun 2010 dengan menyatakan bahwa "Pendidikan Nasional abad XXI bertujuan untuk mewujudkan citacita bangsa, yaitu masyarakat bangsa Indonesia yang sejahtera dan bahagia, dengan kedudukan yang terhormat dan setara dengan bangsa lain dalam dunia global, melalui pembentukan masyarakat yang terdiri dari sumber daya manusia yang berkualitas, yaitu pribadi yang mandiri, berkemauan dan berkemampuan untuk mewujudkan cita-cita bangsanya".

Kemudian Juga BNSP (2011) merumuskan paradigma pendidikan nasional abad 21 yang meliputi: (1) pendidikan yang berorientasi pada ilmu pengetahuan dengan keseimbangan yang wajar, (2) pendidikan harus dibarengi dengan penanaman sikapsikap luhur, (3) pendidikan setiap jenjang harus memenuhi frontliner ilmu; (4) perlu ditanamkan jiwa kemandirian, (5) perlu konvergensi ilmu, (6) perlu memperhatikan aspek kebhinekaan, (7) pendidikan untuk semua, (8) perlu monitoring dan evaluasi pendidikan.

Menurut Muslich dan Zainal, (2011) Pendidikan karakter adalah sesuatu yang harus dilakukan dalam upaya menghadapi

berbagai tantangan pendidikan dengan pergeseran karakter yang dihadapi saat ini. Pendidikan karakter memiliki tujuan pengembangan kemampuan seseorang untuk memberikan keputusan yang memilih dengan keputusan yang tepat, memelihara apa yang baik dan terbaik, dan mewujudkan kebaikan itu dalam kehidupan sehar-hari dengan sepenuh hati tanpa mengedepankan timbal balik dalam pengorbanan.

Menurut Redhana (2019) Persiapan dalam menjadikan sumber daya manusia yang menguasai keterampilan abad ke-21 akan lebih efektif jika ditempuh melalui jalur pendidikan dari setiap tingkat dengan kemampuan yang dibekali. Perubahan kurikulum telah dilakukan oleh pemerintah Indonesia. Pada jenjang sekolah menengah ke bawah telah diterapkan Kurikulum 2013 dengan berbagai perbaikannya yang memakan waktu lama. Kurikulum 2013 sesungguhnya telah sebagian besar mengakomodasi keterampilan abad ke-21, yang dilihat dari standar isi, standar proses, maupun standar penilaian. Pada standar proses, misalnya, pendidik diharuskan menerapkan pembelajaran dengan pendekatan saintifik hal itu juga dilakukan dalam pembelajaran Penjasorkes khususnya. Masalah yang dihadapi kebanyakan pembelajaran yang dilaksanakan adalah pembelajaran yang masih berpusat pada pendidik (teacher-centered) atau dalam arti pembelajaran dengan metode ceramah. Akibatnya, peserta didik tidak dapat menguasai keterampilan abad ke-21 secara optimal. Oleh karena itu, reformasi pembelajaran yang menggeser dari pembelajaran yang berpusat pada pendidik ke pembelajaran yang berpusat pada peserta didik merupakan jawaban dari upaya untuk mengembangkan keterampilan abad ke-21 pada peserta didik yang pada kehidupan sekarang sudah mengetahui pengetahuan dan teknologi lebih dini. Karena adanya teknologi yang memudahkan mengakses dan mengetaui segala hal yang ada.

Pemanfaatan ICT dalam hal ini adalah internet telah dimulai di sejumlah institusi pendidikan. Secara konsep pembelajaran dengan ICT bisa di lakukan dengan kelas maya atau dalam arti Virtual learning memiliki 
Jurnal Kejaora: Jurnal Kesehatan Jasmani dan Olah Raga

ISSN: 2541-5042 (Online)

ISSN: 2503-2976 (Print)

Volume 5 Nomor 1, Edisi April 2020

potensi yang tidak sederhana dalam meningkatkan kualitas. Menurut Yusuf (2010) Pemanfaatan tekonologi informasi dan komunikasi dalam pendidikan mutlak dilakukan untuk menjawab permasalahan di bidang pendidikan terutama akses dan pemerataan serta mutu pendidikan. Kebijakan dan standarisasi mutu pendidikan menjadi pondasi yang harus dibangun untuk mendukung pendidikan berbasis ICT yang efektif dan efisien. Pendidikan diantaranya potensi dalam memberikan peluang berkomunikasi antara peserta belajar dan penyelenggara/pengajar serta komunikasi antar peserta belajar, bahan belajar yang tidak terikat oleh ruang dan waktu. Pemanfaatan ICT dalam dunia pendidikan khususnya pendidikan jasmani salah satu permasalahan yang ada adalah kemampuan guru dalam menggunakan teknologi hal ini juga dibarengi dengan keterbatasan fasilitas yang tersedia sekolah.

Sehingga sudah bertentangan dengan program yang sedang berkembang bahwasa pemanfaatan ICT sebagai model terbaru dalam pembelajaran yang ditawarkan dalam pendidikan, namun pada dasarnya banyak yang tidak dapat memanfaatkan karena tidak adanya proses yang signifikan karena tidak ada penangan yang langsung dilaksanakan. Di era yang serba teknologi, patut untuk dipertanyaan kenapa hal ini bisa terjadi di setiap sekolah yang berada di wilayah lingkup Kota Bandarlampung. Sehingga dilakukan penelitian ini untuk bisa mengetahui dilapangan tentang pemahaman teknologi yang di miliki oleh guru penjas itu sendiri. Kemudian nanti dapat disimpulkan masalah sebenarnya yang dihadapi dilapangan depan pengetahuan yang harus dilakukan.

\section{METODE}

Penelitian ini bertujuan untuk mengetahui pemanfaatan media pembelajaran berbasis ICT ole guru di Kota Bandar Lampung. Penelitian ini menggunakan sampel guru dari tingkat SD, SMP dan SMA dengan tidak membedakan jenis kelamin dengan metode survey, sehingga penelitian ini menjadi penelitian dasar untuk kedepan dapat dilakukan

penelitian lanjutan yang menghasilkan permasalahan baru dilapangan yang berkaitan dengan ICT sebagai media pembelajaran. Menurut Sugiyono (2013) pengertian metode adalah : "Penelitian yang dilakukan dengan menggunakan angket sebagai alat penelitian yang survey dilakukan pada populasi besar maupun kecil, tetapi data yang dipelajari adalah data dari sampel yang diambil dari populasi tersebut, sehingga ditemukan kejadian relatif, distribusi, dan hubungan antar variabel, sosiologis maupun psikologis". Tujuan penelitian survey adalah untuk memberikan gambaran secara mendetail tentang latar belakang, sifat-sifat, serta karakter-karakter yang khas dari kasus atau kejadian suatu hal yang bersifat umum.

Penelitian ini merupakan jenis penelitian deskriptif kuantitatif adalah penelitian yang dilakukan terhadap variabel mandiri, yaitu tanpa membuat perbandingan, atau menghubungkan dengan variabel yang lain (Sugiyono, 2014)

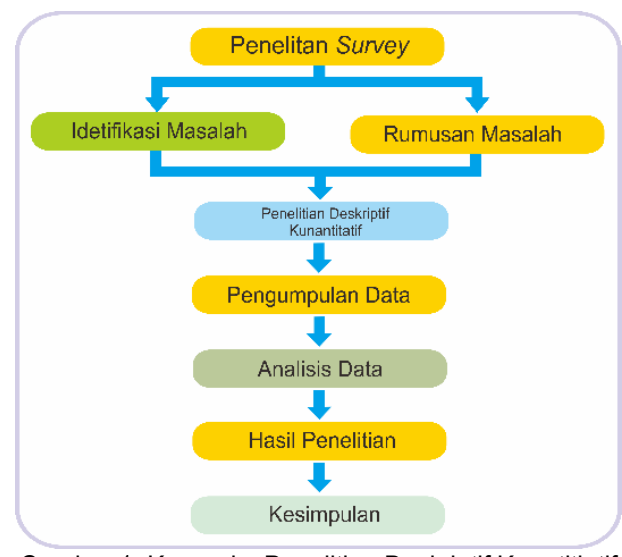

Gambar 1. Kerangka Penelitian Deskriptif Kuantitiatif

Berdasarkan Gambar 1 penelitiannya selalu dimulai dari adanya permasalahan atau ganjalan, yang merupakan suatu kesenjangan yang dirasakan oleh peneliti. Kesenjangan tersebut terjadi karena adanya perbedaan kondisi antara kondisi nyata dengan kondisi harapan. Data yang diperoleh berupa angka maka cara mendeskripsikan data dapat dilakukan dengan menggunakan statistik deskriptif. Tujuan dilakukan analisis deskriptif dengan menggunakan teknik statistika adalah untuk meringkas data agar menjadi lebih mudah dilihat dan dimengerti 
Jurnal Kejaora: Jurnal Kesehatan Jasmani dan Olah Raga

ISSN: 2541-5042 (Online)

ISSN: 2503-2976 (Print)

Volume 5 Nomor 1, Edisi April 2020

Sugiyono (2014) berpendapat bahwa skala Likert digunakan untuk mengukur sikap, pendapat, dan persepsi seseorang atau sekelompok orang tentang fenomena sosial. Jawaban setiap item instrumen yang menggunakan skala likers mempunyai gradasi yang sangat positif sampai negatif. Adapun alternatif jawaban dengan menggunakan skala Likert, yaitu dengan memberikan skor pada masing-masing jawaban pertanyaan alternatif 5 kategori yaitu : Sering sekali, sering, sedang, kurang dan kurang sekali.

Pengkategorian disusun dengan lima kategori yaitu baik sekali, baik, sedang, kurang, dan kurang sekali. Untuk menentukan kriteria skor dengan menggunakan Penilaian Acuan Norma (PAN) dalam skala sebagai berikut:

Tabel 1. Pengkategorian

\begin{tabular}{clc}
\hline No & \multicolumn{1}{c}{ Interval } & Kategori \\
\hline 1 & $M+1.5 \mathrm{SD}<\mathrm{X}$ & Sering sekali \\
\hline 2 & $\begin{array}{l}\mathrm{M}+0,5 \mathrm{SD}<\mathrm{X} \leq \mathrm{M}+1,5 \\
\mathrm{SD}\end{array}$ & Sering \\
\hline 3 & $\mathrm{M}-0,5 \mathrm{SD}<\mathrm{X} \leq \mathrm{M}+0,5 \mathrm{SD}$ & Sedang \\
\hline 4 & $\mathrm{M}-1,5 \mathrm{SD}<\mathrm{X} \leq \mathrm{M}-0,5 \mathrm{SD}$ & Kurang \\
\hline 5 & $\mathrm{X} \leq \mathrm{M}-1,5 \mathrm{SD}$ & Kurang Sekali \\
\hline
\end{tabular}

Keterangan :

$\begin{array}{ll}\mathrm{M} & =\text { Nilai Rata-Rata (Mean) } \\ \mathrm{X} & =\text { Skor } \\ \mathrm{SD} & =\text { Standar Deviasi }\end{array}$

Berdasarkan Sudijono (2011) setelah data dikelompokan dalam setiap kategori, kemudian mencari presentase masingmasing data dengan rumus persentase sebagai berikut :

Keterangan:

$$
P=\frac{F}{N} X 100 \%
$$

$\mathrm{P} \quad=$ Angka presentase

$\mathrm{F} \quad=$ Frekuensi

$\mathrm{N} \quad=$ Jumlah subjek atau responden

$100 \%=$ Nilai tetap

\section{HASIL DAN PEMBAHASAN}

Pada penelitian ini terdapat 92 responden guru dengan berbagai tingkatan

mengajarnya dari SD/MI, SMP/MTS dan SMA/MA.seperti pada tabel berikut.

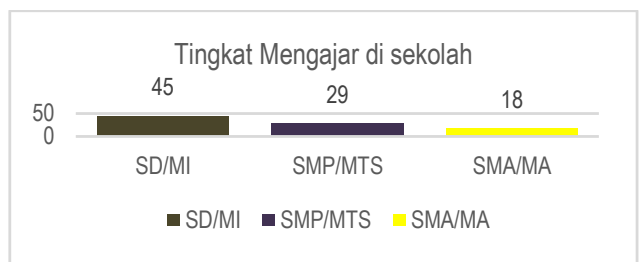

Gambar 2. Tingkat Mengajar Guru Di Sekolah

Dari gambar di atas terdapat jumlah guru yang menjadi responden penelitian pada jenjang SD 45 guru, SMP 29 guru dan SMA 18 guru.

Dilihat dari data yang data individu guru per juli 2019 manajemen dapodik kota Bandar lampung. Yang sudah guru memiliki sertifikasi pendidik di Kota Bandar Lampung sebagai berikut:

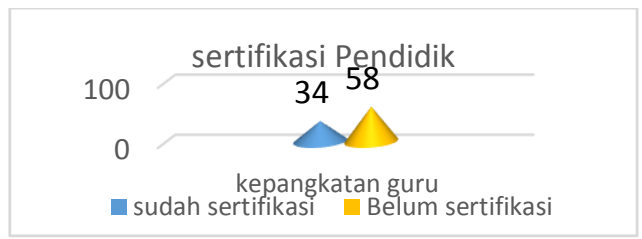

Gambar 3. Diagram sertifikasi pendidik

Dari Gambar 3 didapat bahwasannya guru sertifikasi lebih sedikit dari yang belum sertifikasi. Di dapat dengan melihat biodata guru yang terdaftar pada data pokok guru di Kota Bandar Lampung yang di ambil sampel sebanyak 92 guru.

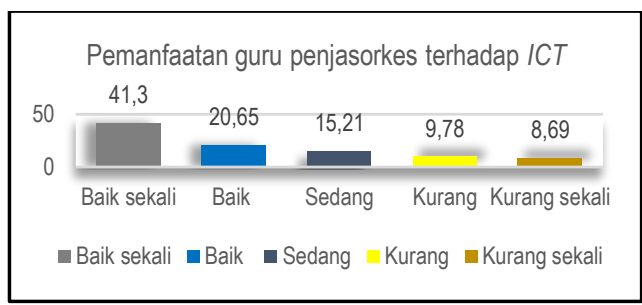

Gambar 4 Diagram hasil penelitian faktor pengetahuan guru penjasorkes terhadap ICT

Berdasarkan hasil penelitian pemanfaatan media pembelajaran berbasis ICT bagi guru Penjasorkes di Kota Bandar Lampung berdasarkan faktor Pengetahuan guru Penjas terhadap ICT berada pada kategori baik sekali terdapat 38 guru dengan presentase sebesar $41,30 \%$, baik terdapat 19 
Jurnal Kejaora: Jurnal Kesehatan Jasmani dan Olah Raga

ISSN: 2541-5042 (Online)

ISSN: 2503-2976 (Print)

Volume 5 Nomor 1, Edisi April 2020

guru sebesar $20,65 \%$, sedang terdapat 14 guru sebesar $15,21 \%$, kurang terdapat 9 guru sebesar $9,78 \%$, dan kurang sekali terdapat 8 guru sebesar $8,69 \%$.

Rincian mengenai pemanfaatan media pembelajaran berbasis ICT oleh guru penjasorkes di Kota Bandar Lampung tahun 2019 berdasarkan faktor; (1) Pengetahuan guru penjas terhadap ICT, (2) Penggunaan dan pemanfaatan media pembelajaan berbasis ICT, (3) dan Pengembangan media

pembelajaran berbasis ICT adalah sebagai berikut:

1. Pengetahuan guru penjasorkes terhadap ICT

Pengetahuan guru penjas tentang media pembelajaran berbasis ICT memiliki kategori dan kemampuan yang berebedabeda. Pada gambar diagram membuktikan bahwa:

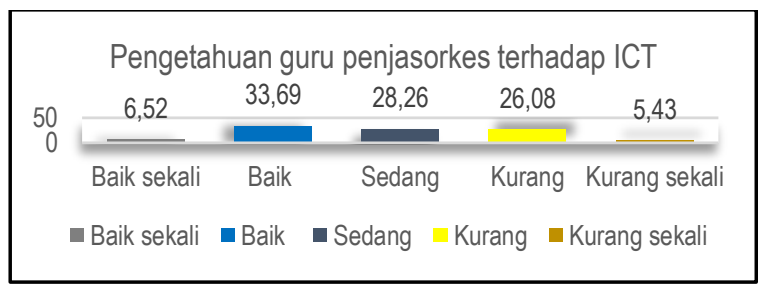

Gambar 5. Diagram Hasil Penelitian Faktor Pengetahuan Guru Penjasorkes Terhadap ICT

Berdasarkan hasil penelitian pemanfaatan media pembelajaran berbasis ICT bagi guru Penjasorkes di Kota Bandar Lampung berdasarkan faktor Pengetahuan guru Penjas terhadap ICT berada pada kategori baik sekali terdapat 6 guru dengan presentase sebesar $6,52 \%$, baik terdapat 31 guru sebesar $33,69 \%$, sedang terdapat 26 guru sebesar $28,26 \%$, kurang terdapat 24 guru sebesar $26,08 \%$, dan kurang sekali terdapat 5 guru sebesar $5,43 \%$.
2. Penggunaan dan pemanfaatan media pembelajaan berbasis ICT

Penggunaan ICT sebagai media pembelajaran dan pemanfaatan media pembelajaran berbasis ICT dalam pembelajaran penjas masih dalam kategori yang sedang hal ini dapat dibuktikan di bawah ini:

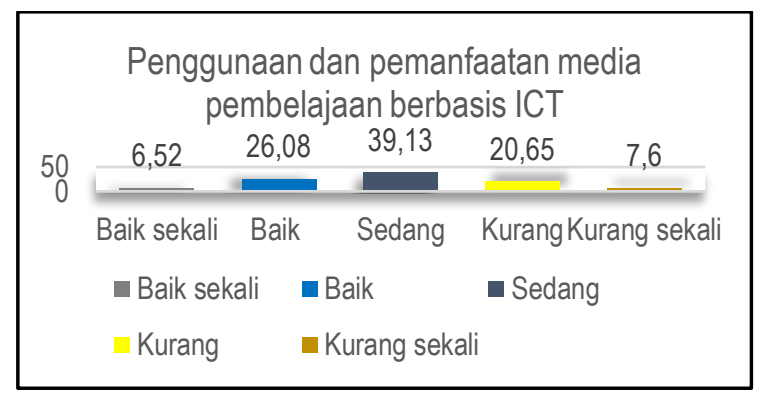

Gambar 6 Diagram Hasil Penelitian Faktor Penggunaan Dan Pemanfaatan Media Pembelajaan Berbasis ICT.

Berdasarkan hasil penelitian pemanfaatan media pembelajaran berbasis ICT bagi guru Penjasorkes di Kota Bandar Lampung berdasarkan faktor Penggunaan dan pemanfaatan media pembelajaan berbasis ICT berada pada kategori baik sekali terdapat 6 guru dengan presentase sebesar $6,52 \%$, baik terdapat 24 guru sebesar 26,08\%, sedang terdapat 36 guru sebesar $39,13 \%$, kurang terdapat 19 guru sebesar $20,65 \%$, dan kurang sekali terdapat 7 guru sebesar $7,60 \%$.

\section{Pengembangan media pembelajaran berbasis ICT}

Pada pembelajaran abad 21 pengembangan dalam membuat media pembelajaran menjadi perioritas utama untuk 
Jurnal Kejaora: Jurnal Kesehatan Jasmani dan Olah Raga

ISSN: 2541-5042 (Online)

ISSN: 2503-2976 (Print)

Volume 5 Nomor 1, Edisi April 2020

memudahkan dalam memberikan materi yang dapat memudahkan murid menerima materi. Berikut gambar umum tentang

pengembangan media pembelajaran berbasis ICT yang dilakukan guru:

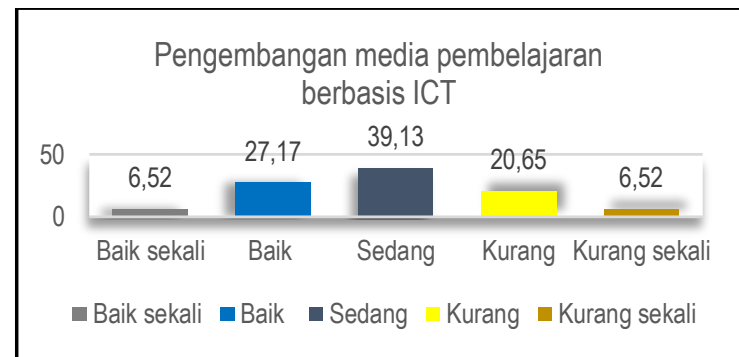

Gambar 7. Diagram Hasil Penelitian Faktor Pengembangan Media Pembelajaran Berbasis ICT.

Berdasarkan hasil penelitian pemanfaatan media pembelajaran berbasis ICT bagi guru Penjasorkes di Kota Bandar Lampung berdasarkan faktor Penggunaan dan pemanfaatan media pembelajaan berbasis ICT berada pada kategori baik sekali terdapat 6 guru dengan presentase sebesar $6,52 \%$, baik terdapat 25 guru sebesar $27,17 \%$, sedang terdapat 36 guru sebesar $39,13 \%$, kurang terdapat 19 guru sebesar $20,65 \%$, dan kurang sekali terdapat 6 guru sebesar $6,52 \%$.

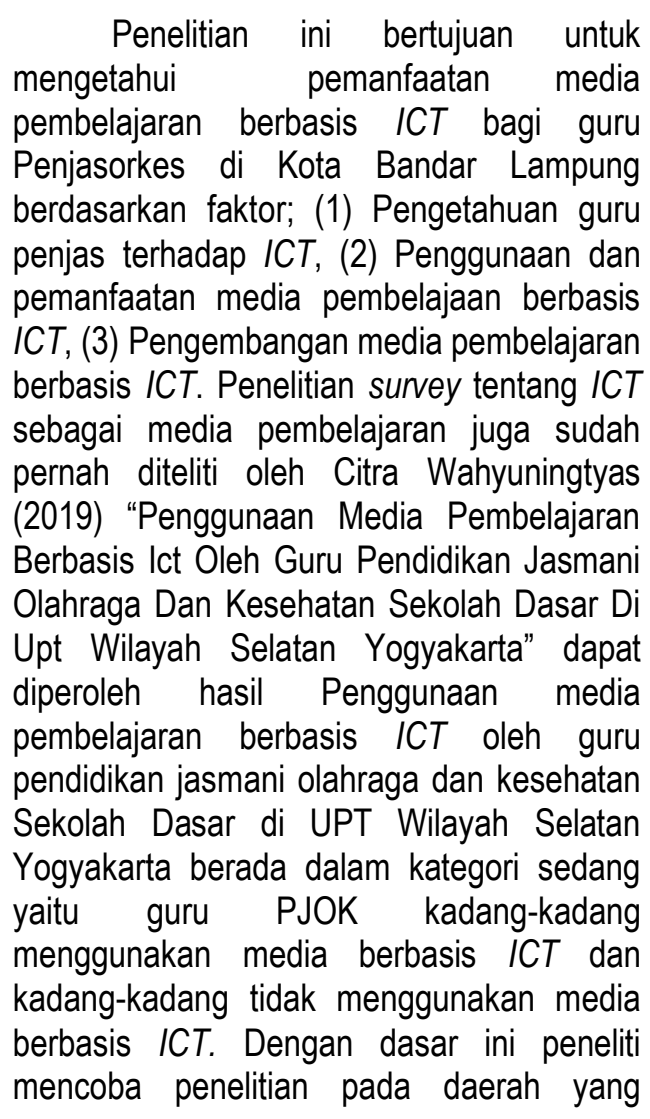

berbeda untuk melihat perbedaan yang ada pada daerah yang diteliti.

Berdasarkan nilai rata-rata yaitu 75 , pemanfaatan media pembelajaran berbasis ICT oleh guru penjasorkes di Kota Bandar Lampung masuk dalam kategori sedang. Penelitian tersebut mengindikasikan bahwa penggunaan seluruh guru PJOK Sekolah Dasar di Kota Bandar Lampung sudah baik memanfaatakan media berbasis ICT dalam permbelajaran PJOK dalam kategori pengetahuan, penggunaan dan pemahaman dalam pemanfaatan ICT. Akan tetapi ada beberapa guru yang kurang baik menggunakan media berbasis ICT pada saat pembelajaran PJOK yang disebahkan fasilitas maupun pengetahuan tentang pemanfaatan ICT. Pemanfaatan media pembelajaran berbasis ICT kategori baik sekali dalam jumlah yang lebih tinggi.

Pemanfaatan media berbasis ICT dalam pembelajaran penjasorkes di Kota bandar Lampung berdasarkan faktor pengetahuan ICT masuk dalam kategori sedang ke bawah. Hasil ICT pengambilan data diketahui bahwa seluruh guru Penjasorkes di Kota Bandar Lampung memanfaatkan sebagai pengetahuan dalam pembelajaran PJOK. Hal ini dilihat dari guru mengetahui tentang pengetahuan microsoft ofiice yang digunakan sebagai keperluan setiap hari, tidak hanya itu juga ppengetahuan pengetahuan komputer dan laptop menjadi poin utama dalam memanfaatkan ICT segaai media pembelajaran. Kuncinya adalah pengetahuan tentang internet rata-rata guru mengetahui dari youtube mencari video pemmbelajaran, 
Jurnal Kejaora: Jurnal Kesehatan Jasmani dan Olah Raga

ISSN: 2541-5042 (Online)

ISSN: 2503-2976 (Print)

Volume 5 Nomor 1, Edisi April 2020

whataap untuk berhubungan lebih mudh dan pembelajaran menggunakan daring dan google class itu guru rata-rata menetahui. Akan tetapi dalam kategori baik sampai ke baik juga besar sehingga perbadingan pengetahuan sedikit berimbang. Hal ini sudah dimanfaatkan namun pengetahuan yang masih kurang dalam memanfaatkan ICT.

Pemanfaatan media berbasis ICT dalam pembelajaran penjasorkes di Kota bandar Lampung berdasarkan faktor penggunaan ICT dalam kategori sedang. Hasil pengambilan data diketahui bahwa seluruh guru Penjasorkes di Kota Bandar Lampung memanfaatkan ICT dalam penggunaan dan pemanfaatan ICT dalam pembelajaran PJOK. Pengunaan dan pemanfaatan microsoft office dalam pembelajaran rata-rata 4 sampai dengan 5 kali pertemuan persemester diguanakan guru untuk menjelaskan pembelajaran agar siswa lebih paham dengan cepat. Penggunaan dan pemanfaatan dalam jarigan internet untuk pembelajaran yang dilakukan guru 6 sampai dengan 7 pertemuan, ini dilhat dari guru menggunakan youtube dan google class sebagai wadah tidak harus belajar di lapangan maupun di kelas namun bisa dari rumah. Guru juga memanfaatkan google class untuk melakukan absen sehingga lebih praktis pemanfaatannya. Akan tetapi dalam penggunaan ICT yang lebih mendalam masih rendah untuk penggunaan karena dari 92 guru, 30 guru baru yang menggunakan ICT dengan baik sisanya dalam kategori kurang dan kurang sekali. Penggunaan ICT dalam pembelajaran Penjasorkes digunakan untuk mempermudah dalam pembelajaran.

Pemanfaatan media berbasis ICT dalam pembelajaran penjasorkes di kota bandar lampung berdasarkan faktor pemahaman media pembelajaran dalan kategori sedang yang paling tinggi. Hasil pengambilan data diketahui bahwa seluruh guru penjasorkes menggunakan pendalam pemahaman ICT dalam pembelajaran PJOK. Pemahaman guru dalam menggunakan ICT sebagai media pembelajaran terbentur dengan fasilitas, karena sebagian besar jawaban guru fasilitas yang tersedia di sekolah masih jarang. Kemudian pelatihan bagi guru persemester juga hanya 1 sampai

2 kali sehingga untuk cepat memahami pemanfaatan ICT sedikit terkedala dan lambat menerimanya walaupun guru dalam satu minggu sekali belajaran media pembelajaran berbasis ICT. Hal ini menyebabkan beberapa guru yang kurang baik Pemahaman ICT pada saat pembelajaran PJOK.

Dari hasil yang dilakukan dengan survey yang dilakukan oleh peneliti di Kota Bandar Lampung, dapat disimpulkan bahwa untuk ketersediaan media pembelajaran sudah tersedia dengan cukup, walaupun jumlahnya masih terbatas karena sarana dan prasarana penunjang lainnya belum lengkap. Sedangkan dalam kaitannya dengan penggunaan media pembelajaran berbasis ICT, sebagian besar guru PJOK lebih banyak menggunakan internet dibandingkan teknologi lain hal ini dikarenakan pengguna yang lebih mudah dan dapat dijangkau dimanapun tempat, pengetahuan, penggunaan dan pemahaman saat pembelajaran PJOK sudah dalam kategori sangat baik penggunaan namun dengan pemahaman yang masih di bawah rata-rada yang dilihat dari kategori sedang dalam pemanfaatan. Hal ini disebabkan karena membutuhkan waktu persiapan yang relatif lebih lama dan akan menyita waktu pembelajaran walaupun medianya sudah tersedia serta perlu ditambah dengan adanya pelatihan yang intensif untuk membuat media pembelajaran yang berkaitan dengan teknologi.

Media dalam hal ini segala sesuatu yang dapat mengantarkan pesan atau informasi belajar dari guru kepada peserta didik dengan cepat dan mudah dipahami, yang dapat merangsang minat belajar siswa untuk menyukai pembelajaran tersebut. Media berbasis ICT yaitu media berupa teknologi komputer, teknologi multimedia, teknologi telekomunikasi dan teknologi jaringan internet yang harus di barengi dengan pengetahuan, penggunaan dan pemahaman dalam pengoprasiannya. Dalam pelaksanaan pembelajaran penjasorkes sebaiknya memanfaatkan media berbasis ICT untuk kelancaran proses pembelajaran PJOK yang lebih menarik dan dapat dengan cepat di terima oleh peserta didik itu. Upaya 
Jurnal Kejaora: Jurnal Kesehatan Jasmani dan Olah Raga

ISSN: 2541-5042 (Online)

ISSN: 2503-2976 (Print)

Volume 5 Nomor 1, Edisi April 2020

guru penjasorkes dengan memanfaatkan media pembelajaran berbasis ICT yang digunakan dalam pembelajaran penjasorkes akan membantu kelancaran pembelajaran dan meningkatkan kualitas serta kuantitas pembelajaran penjasokes itu sendiri. Kemampuan menangkap pembelajaran peserta didik yang berbeda-beda mengharuskan guru untuk memilih dan memnafaatkan media pembelajaran yang tepat agar materi dapat diterima baik oleh peserta didik dengan baik.

\section{KESIMPULAN}

Hasil pembahasan yang telah dikemukakan pada bab di atas, maka dapat diambil kesimpulan bahwa pemanfaatan media pembelajaran berbasis ICT oleh guru penjasorkes di Kota Bandar Lampung dapat diperoleh hasil kategori baik sekali dengan persentase sebesar $41,3 \%$ artinya guru PJOK selalu memanfaatkan media berbasis ICT dengan jumlah paling tinggi, dengan kata lain guru sudah memnafaatankan dan namun harus ada pendampingan untuk pemanfaatan yang lebih intensif, dalam kategori baik sebesar 20,65\% artinya hampir selalu memanfaatkan media berbasis ICT dengan baik, sedang sebesar $15,21 \%$ artinya terkadang digunakan pemanfaatan kadangkadang tidak menggunakan media berbasis ICT bagi guru untuk memberikan pembelajaran penjasorkes, kurang sebesar $9,78 \%$ artinya hampir tidak pernah menggunakan media berbasis ICT yang masih dengan metode pembelajaran langsung yang disebabkan fasilitas tersedia dalam jumlah yang terbatas, dan kurang sekali $5,13 \%$ artinya tidak pernah menggunakan media berbasis ICT karena pemahaman guru untuk memanfaatkan sangat minim, di barengi dengan sarana dan prasarana yang terbatas. Pemanfaatan media pembelajaran berbasis ICT oleh Penjasorkes di Kota Bandar Lampun terkadang digunakan terkadang tidak dimanfaatkan. Namun jumlah emanfatkan lebih tinggi tapi masih dengan kapasitas pemahaman yang setiap hari digunakaanya, sedangkan ada juga dalam kategori yang kurang dalam kategori guru ini perlu adanya

pelatihan untuk peningkatan dalam memanfaatkan ICT.

Peneliti memberkan saran kepada guru penjasokres untuk meningkatkan pengetahuan, penggunaan dan pemahaman ICT yang dilakukan dengan pelatihan tentang ICT yang digunakn untuk emngasah kemampuan sertasoft skill yang dimilik guru untuk mempermudahkan dalam memberikan pembelajaran dengan media pembelajaran yang baik.

\section{DAFTAR PUSTAKA}

Aip, S dan Nurhadi, S. (2009). Pendidikan Jasmani dan Kesehatan. Jakarta: Depdikbud Dirjen Perguruan Tinggi.

Basuki, S. (2016). Pendekatan Saintifik pada Penjasorkes Dalam Rangka Membentuk Jati Diri Peserta Didik. Jurnal Pendidikan Jasmani: Univeristas Lambung Mangkurat. 12(2) , 117-124.

BSNP. 2011. Laporan BSNP Tahun 2010. Jakarta.

Erawati, D dkk. (2015).Peranan Tik Dalam Pembelajaran Penjas Di Sekolah Tesis. Program Studi (S2) Pendidikan Olahraga, Program Pascasarjana. Universitas Negeri Jakarta.

Mayasari, T. dkk. (2016). Apakah Model Pembelajaran Problem Based Learning Dan Project Based Learning Mampu Melatihkan Keterampilan Abad 21?. JPFK. II(1): 48 - 55.

Rahim, M.Y. (2011). Pemanfaatan ICT sebagai Media Pembelajaran dan Informasi pada UIN Alauddin Makasar: Sulesana 6(2) : 127-135.

Redhana, I.W. (2019). Mengembangkan Keterampilan Abad Ke-21 Dalam Pembelajaran Kimia. Jurnal Inovasi Pendidikan Kimia, XIII(1): 2239 2253.

Rusman, dkk. (2011). Pembelajaran Berbasis Teknologi Informasi dan Komunikasi: Mengembangkan Profesionalisme Guru. Rajawali Pers. Jakarta: PT. Raja Grafindo Persada.

Sugiyono. (2013). Metode Penelitian Kuantitatif, Kualitatif dan R\&D. Bandung: Alfabeta 
Jurnal Kejaora: Jurnal Kesehatan Jasmani dan Olah Raga

ISSN: 2541-5042 (Online)

ISSN: 2503-2976 (Print)

Volume 5 Nomor 1, Edisi April 2020

(2014). Metode Penelitian Pendidikan Pendekatan Kuantitatif,Kualitatif, dan $R \& D$. Bandung: Alfabeta.

Suryani, N. (2015). Pengembangan Media Pembelajaran Berbasis IT, Prosiding of Workshop Nasional Surakarta; 112.

Swadesi, I.K.I.K, dan Nyoman, I. (2018). Pengembangan Media Pembelajaran PJOK berbasis ICT di SMP: Seminar Nasional Riset Inovatif 2018, SENARI ke -6: 274-281.

Wahyuningtyas, C. (2019). Penggunaan Media Pembelajaran Berbasis ICT Oleh Guru Pendidikan Jasmani Olahraga Dan Kesehatan Sekolah Dasar Di Upt Wilayah Selatan Yogyakarta. Skripsi. Program Studi Penjas SD, Universitas Negeri Yogyakarta :Yogyakarta.

Wijaya, M.A. (2011). Buku Ajar PrinsipPrinsip Pengembangan dan Modifikasi Cabang Olahraga. Universitas Pendidikan Ganesha: Singaraja.

Wulandari, S. (2016). Kinerja Lembaga Penjaminan Mutu Pendidikan (Lpmp) Dalam Meningkatkan Kompetensi Dan Profesionalisme Tenaga Pendidik Di Bandar Lampung (Skripsi). Fakultas IImu Sosial Dan IImu Politik, Universitas Lampung.

Yusuf, E.A. (2010). Pemanfaatan ICT Dalam

Pendidikan. Kebijakan Dan

Standarisasi Mutu,Dosen Pasca Sarjana Unpak.

Zubaidah, S. (2016). Keterampilan Abad Ke21: Keterampilan Yang Diajarkan Melalui Pembelajaran, Seminar Nasional Pendidikan. SintangKalimantan Barat; 1-17. 